\author{
P. Grossoni, P. Bruschi, F. Bussotti, M. Pollastrini \& F. Selvi
}

\title{
The taxonomic interpretation of Mediterranean oaks of Quercus sect. Quercus (Fagaceae): uncertainties and diverging concepts
}

\begin{abstract}
Grossoni, P., Bruschi, P., Bussotti, F., Pollastrini, M. \& Selvi, F.: The taxonomic interpretation of Mediterranean oaks of Quercus sect. Quercus (Fagaceae): uncertainties and diverging concepts. - Fl. Medit. 31 (Special Issue): 271-278. 2021. — ISSN: 1120-4052 printed, 2240-4538 online.

The high degree of polymorphism found in the genus Quercus is certainly the main cause of the divergent taxonomic treatments that have often generated more uncertainties, if not confusion, than clarity. However, in recent years, also thanks to the use of molecular investigation techniques, several doubts have now been overcome. In this paper we summarized the main literature on the topic and provide a synthetic evaluation of the systematic position of the Italian taxa belonging to the so-called "Quercus pubescens group" ("downy oaks").
\end{abstract}

Key words: Quercus pubescens complex, downy oaks, Mediterranean Basin.

\section{Introduction}

Oaks (Quercus L., Fagaceae Dumort.) are widely distributed in the Northern hemisphere playing important roles in providing forest products (timber, fuel wood, cork, mushrooms, extracts and derivatives, etc.), in conservation of biodiversity, protection of landscape and all related ecosystem services. In Italy, oak forests occupy about $2,873,000$ ha, corresponding to $29.4 \%$ of the entire national forest area (Corona $\&$ al. 2004). The genus Quercus includes a large number of species. Camus (1936-39) quoted about 800 taxa, while Krüssmann (1986) reported about 450 species. The most recent taxonomic revisions tend to reduce the number of species by putting more emphasis on similar characters and adopting a wider species concept, so that currently between 300 and 350 species are recognized. Denk \& al. (2017) provide a list of 858 names among species, synonyms, subspecies, hybrids, and dubious species.

The classification of oak species is under debate since centuries. Recently Denk \& Grimm (2010) and Denk \& al. (2017) revised the past classifications (Ørsted 1871; Schwarz 1936-39; Camus 1936-39; Nixon 1993) and proposed a new one based on a phylogenetic and molecular approach. According to this recent classification, Quercus is subdivided into two subgenera, Q. subg. Quercus and Q. subg. Cerris, 
both including several sections. Oak species have very different general habit (trees to shrubs), phenology (evergreen, deciduous, semi-deciduous), and ecological requirements (from tropical to boreal and Mediterranean). Several species display strong polymorphism and a remarkable ability to form hybrids, making their taxonomic limits, and the species concept itself, quite elusive.

As early as in 1911, Antonino Borzì had deemed that the genus Quercus did provide "[...] the perfect negation of the concept of species $[\ldots]$ ", followed by the statement "[...] it is an immense chaos [...]". Still in the last quarter of the last century, Burger (1975) stressed the difficulty of applying the biological species concept in Quercus, due to relatively frequent gene exchanges between different species. A few years later, referring to the "ability" of $Q$. alba L. and Q. stellata Wangenh. to form hybrids with other 11 species of the eastern United States, Whittemore \& Schaal (1991) confirmed that oak species are easily interfertile due to weak and incomplete interspecific reproductive barriers. On the other hand, the lack of sharp morphological delimitations, together with low interspecific genetic differentiation, have often been interpreted as the consequence of natural hybridisation in Quercus (Bruschi \& al. 2000; Salvini \& al. 2009). Incorporation of heterospecific alleles, through hybridization and regression, would yield reduced interspecific distances compared to values expected for taxa that had been fully isolated genetically subsequent to speciation. Similar considerations can be found in Le Hardÿ de Beaulieu \& Lamant (2010), who published an illustrated world monograph of Quercus, that can be considered evolved from the work of Aimée Camus (1936-1939). Based on data collected across the genus in different continents, these two authors also stressed the difficulty of applying the biological species concept to oaks. In fact, several complexes of sympatric "species" exist in which taxa are capable of frequent gene exchange, thus reducing their morphological divergence. According to Le Hardÿ de Beaulieu \& Lamant (2010) it would be more correct to use the term "multispecies" when referring to these complexes.

Gene flow and hybridization have certainly played an important role also in the evolutionary history of oaks of the Mediterranean Basin. This region is considered a hotspot of plant biodiversity (Médail \& Quézel 1999), resulting from its biogeographic history and natural heterogeneity of habitats and environmental conditions. Events like migration, micro-evolution, isolation in glacial refugia, range disjunctions and others have favoured the formation of many endemic species but also local phenotypic variation in populations sometimes classified as distinct entities or taxa. Moreover, the strong and long impact of human activities on habitats, landscape and vegetation, especially forest fragmentation, has contributed to promote hybridization and introgression between taxa in many plant groups (Médail \& al. 2019).

In 1997 some of us (Bussotti \& Grossoni 1997) published a comparative analysis of the differences between several classifications of taxa of Quercus described from the Mediterranean region (Camus 1936-1939; Greuter \& al. 1986; Krüssmann 1986; Nixon 1993; Pignatti 1982; Schwarz 1964, 1993). They found that these classifications had several nomenclatural and taxonomic discrepancies, the use of names and synonyms being inconsistent and based on contrasting species concepts. This resulted in doubts, uncertainties and contradictory conclusions. That analysis was subsequent- 
ly repulished in the journal Forêt Méditerranéenne (Bussotti \& Grossoni 1998). It pointed out that the greatest perplexities and uncertainties concerned the groups " $Q$. pubescens - Q. petraea" and "Q. faginea - Q. lusitanica", in which a high genetic diversity is associated with the tendency to differentiate numerous local phenotypes along almost continuous morphological gradients, without any clear correlation with ecological or geographical factors, thus making it very difficult to separate welldefined taxa.

The present contribution aims at revisiting the past and current classifications of the species belonging to $Q$. subg. Quercus in Italy, with special reference to the group $Q$. pubescens - Q. petraea group and related entities of the so-called "downy oaks".

\section{Taxa of Quercus sect. Quercus in Italy}

Among the species currently placed in Quercus sect. Quercus, Q. robur was the only one described by Linnaeus (1753). Fiori (1923-1925) still used this name for the whole complex, albeit dividing it into numerous infraspecific taxa, many of which are currently obsolete. Subsequently, Di Tella (1930) and Merendi (1930) distinguished the English oak ("Q. pedunculata Ehrh.") from the sessile oak, in which they included both "Q. sessilis Ehrh." and "Q. lanuginosa Lam.". All these entities were placed by Fiori (1930) in $Q$. robur and were generically called referred to as "querce roveri".

More recent classifications are summarized in Table 1, which shows a persistent variability in the number of species, as well as the presence of numerous doubtful species. The unequivocally recognized species are $Q$. robur L., Q. petraea (Matt.) Liebl., Q. pubescens Willd. and Q. frainetto Ten., while Q. pyrenaica Willd., already considered as rare and present only in the Val di Susa (Piemonte) in the first edition of Flora d'Italia (Pignatti 1982), was excluded from the native Italian flora in the second edition (Brullo 2017) and by Brullo \& al. (1999) and Brullo (2017), whereas Bartolucci \& al. (2018) still include Q. pyrenaica in their list of the Italian native flora. These authors subdivided each $Q$. petraea and $Q$. robur into two subspecies, while Brullo (2017) considered Q. brutia Ten., omitted from Table 1, as a "phantom species".

Recently, Bussotti (2020) summarised a synoptic table with the main morphological characters of the three principal species of the «robur-petraea-pubescens» complex; among them, $Q$. robur presents the lowest identification difficulty, due to the uniqueness and stability of the characters that consistently separate it from all other species. On the other hand, the distinction between $Q$. pubescens and Q. petraea is often uncertain due to the lack of stable and reliable morphological characters concerning twigs (shape, size, presence/absence of pubescence), leaves (size, shape, pubescence) and fruits (cupule of the acorns). Indeed, most of these characters show a continuous series of intermediate states connecting one species to the other and are often widely variable even within the same population or geographic area. 
Table 1. List of native taxa in Quercus subgen. Quercus accepted and quoted for Italy in relevant recent literature and web sources.

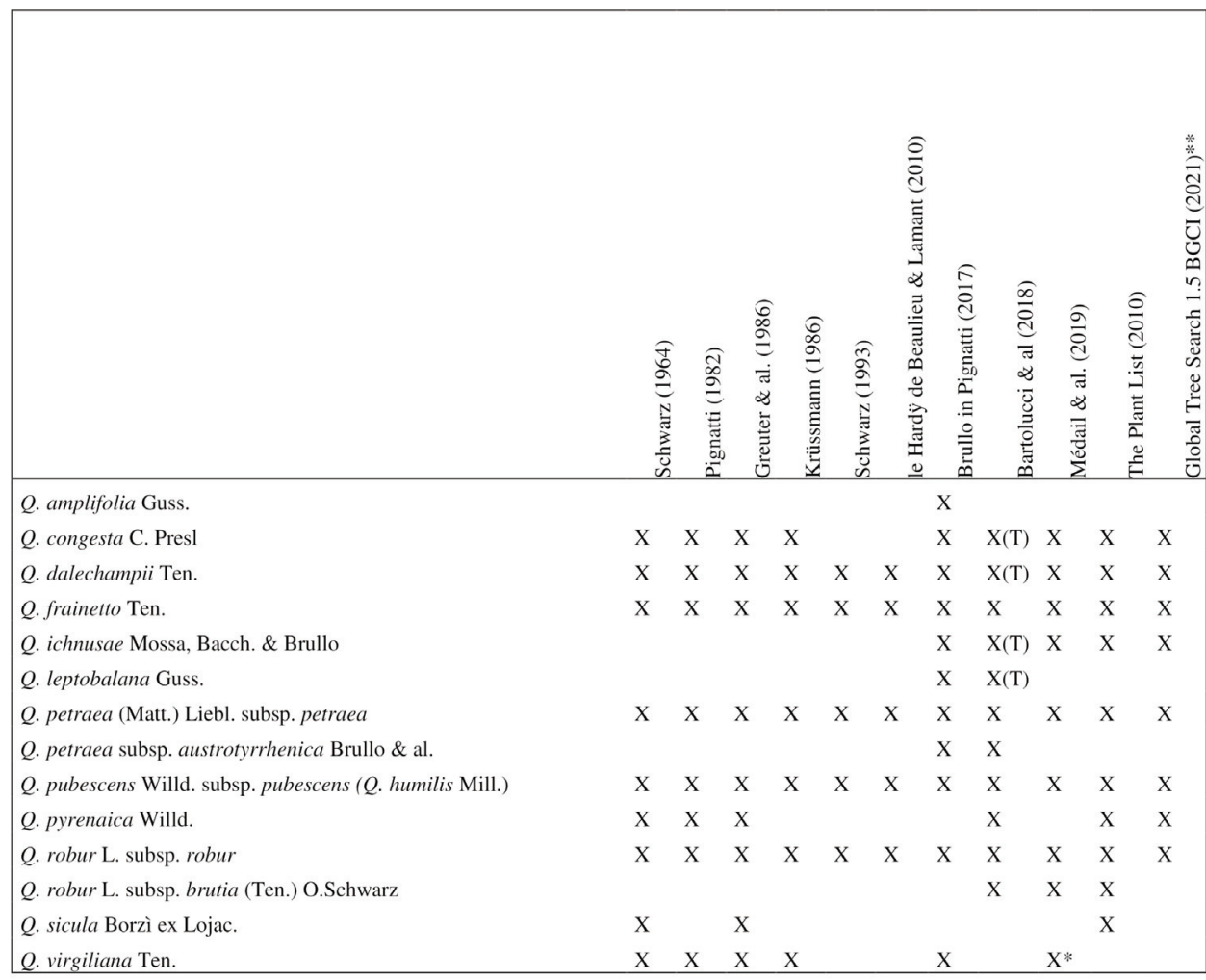

* treated as " $Q$. pubescens subsp. virgiliana", without authorship of that combination.

(T): as taxonomically doubtful

$* *=$ https://tools.bgci.org/global_tree_search.php

\section{The downy oaks}

Quercus pubescens is a very polymorphic species, and its circumscription includes a swarm of closely related entities, that are currently still considered as independent taxa in some recent accounts of the Italian flora, as reported in Table 1.

Considering the species within $Q$. pubescens "lato sensu", compared to those recognized by Brullo (2017), the list by Bartolucci \& al. (2018) does not include Q. virgiliana (Ten.) Ten., nor Q. amplifolia Guss., while Q. ichnusae Mossa \& al. and Q. leptobalana Guss. are included. Schwarz (1993) also reported Q. sicula Borzì ex Lojac., although, at the time, it had already been qualified as a "mistake" by Antonino Borzì (Brullo \& al. 1999). There is also an inconsistency in the spelling of one epithet: "leptobalana" in Bartolucci \& al. (2018) and "leptobalanos" in Brullo \& al. (1999) and Brullo (2017), a discrepancy which has its roots in the $19^{\text {th }}$ century and, evidently, persists to date (both names 
are attributed to Guss. 1844),, whereas $Q$. pubescens has been definitively accepted instead $Q$. humilis Mill. (Q. humilis is now accepted as synonymous only for $Q$. pubescens subsp. pubescens).

The entities related to the "downy oak" complex were identified and determined for the first time in Sicily, Sardinia or southern Calabria; according to Brullo \& al. (1999) and Brullo (2017) the Italian range of $Q$. pubescens is limited to the peninsular and continental regions, it being replaced in the large islands and in some areas of the southern peninsula by other species of the same complex, Quercus virgiliana and Q. dalechampii Ten.; these have also been reported in various countries of south-eastern Europe and the Balkans. However, there is much uncertainty as to the correctness of these reports, due to the often contradictory descriptions of the corresponding entities (Di Pietro \& al. 2012) and an overly subjective approach to recognition and classification. Arrigoni (2018), due to the lack of reproductive isolation, does not recognize $Q$. virgiliana and considers it as a synonymy of $Q$. pubescens, together with all the other putative species of the group (Q. congesta $\mathrm{C}$. Presl, $Q$. amplifolia, $Q$. ichnusae, and Q. leptobalana)

A first morphometric approach to discriminate $Q$. pubescens from other species of the same group in Sicily was attempted by Di Noto \& al. (1995), without conclusive results. Based on the study of 20 Q. pubescens populations randomly sampled in central and southern Italy, Bruschi \& Grossoni (2004) observed a high morphological and molecular variability (with populations from Sicily, Sardinia and Calabria showing a higher average diversity than the others). While morphological characters (those related to the acorn cap) allowed these authors to identify five different groups, no differences were detected at molecular level. The same conclusions were drawn by Franjić \& al. (2006) in a molecular study on $Q$. pubescens populations of Southern Croatia: "This study confirms a high variability of Q. pubescens populations, but differences were not so big to confirm the opinion of existence of several species in this area". Di Pietro \& al. (2016) found that all morphological characters analysed in 24 Apulian populations exhibited continuous variation, so that none of them could be used as a character to discriminate between populations; they concluded that it "is unlikely that more than one species belonging to the Quercus pubescens complex occurs in the Apulia region". Di Pietro \& al. (2020a, b, c) expanded this approach by comparing morphological and genetic aspects of seven taxa of the Q. pubescens group (Quercus pubescens, Q. amplifolia, Q. congesta, Q. dalechampii, Q. ichnusae, $Q$. leptobalanos, $Q$. virgiliana) in southern Italy and the islands (Sicily and Sardinia), concluding that "In light of the results obtained, the taxonomic classification for the pubescent white oaks currently reported in the major Italian floras and checklists for the study area was not confirmed by molecular analyses".

Hybridisation within Quercus sect. Quercus appears to be extensive (Rushton 1993), and recorded hybrids between $Q$. petraea and Q. robur (Bacilieri \& al. 1995) and between $Q$. petraea and $Q$. pubescens (Salvini \& al. 2009) are common and widespread.

The results of a parentage analysis carried out through microsatellite markers on a mixed $Q$. petraea - Q. pubescens population (Salvini \& al. 2009) showed an asymmetrical gene flow with a predominant component in the direction $Q$. petraea versus $Q$. pubescens. These results also showed that intermediate individuals are pollen-receptive towards both species and their high pollen viability provides potential for fostering high rates of introgression. 


\section{Conclusions}

The accurate morphological and genetic analyses, carried out by the various research groups mentioned in this article, allow us to exclude that the multitude of botanical names associated with the $Q$. pubescens group is mirroring effective differentiation into welldefined species, thus supporting the conclusions of Wellstein \& Spada (2015): "While some schools in southern Europe still emphasize the distinctness and the species status of many taxa described during the earliest botanical surveys, the current trend is toward rejecting many names and considering them as synonyms".

Polymorphism is frequent in oak species. Corti (1959), for example, mentioned 175 infraspecific taxa under Quercus ilex, that is considered a non-controversial species. Q. ilex is characterised by a set of well-defined and generally accepted characters, whereas the characterization of the "white oaks" is more subtle and their evaluation can be affected by a certain degree of subjectivity.

In the absence of selective reproductive barriers, hybridization can generate phenotypes with appreciable morphological and ecological diversity, even with extreme forms that can sometimes be quite distinctive. However, these phenotypes are usually distributed along continuous morphological gradients, and have no or little geographic or ecological distinctness, being often overlapping and mixed in the same locality or forest areas.

However, a taxonomic simplification does not imply a simplification at the genetic and ecological level. The deciduous oak forests of southern Italy are a large reserve of genetic variability that is an important asset for the adaptation of European forests to climate change. Southern provenances of deciduous oaks are good candidates to restore the Central European forests affected by drought in a context of "assisted migration" (Bussotti \& al. 2015).

\section{References}

Arrigoni, P. V. 2018: Flora Analitica della Toscana, 4. - Firenze.

Bacilieri, R., Ducousso, A. \& Kremer, A. 1995: Genetic, morphological and phenological di differentiation between Quercus petraea (Matt.) Liebl. and Quercus robur L. in a mixed stand of northwest of France. - Silvae Genetica 44: 1-10.

Bartolucci, F., Peruzzi, L., Galasso, G., Albano, A., Alessandrini, A., Ardenghi, N. M. G., Astuti, G., Bacchetta, G., Ballelli, S., Banfi, E., Barberis, G., Bernardo, L., Bouvet, D., Bovio, M., Cecchi, L., Di Pietro, R., Domina, G., Fascetti, S., Fenu, G., Festi, F., Foggi, B., Gallo, L., Gottschlich, G., Gubellini, L., Iamonico, D., Iberite, M., Jiménez-Mejías, P., Lattanzi, E., Marchetti, D., Martinetto, E., Masin, R. R., Medagli, P., Passalacqua, N. G., Peccenini, S., Pennesi, R., Pierini, B., Poldini, L., Prosser, F., Raimondo, F. M., Roma-Marzio, F., Rosati, L., Santangelo, A., Scoppola, A., Scortegagna, S., Selvaggi, A., Selvi, F., Soldano, A., Stinca, A., Wagensommer, R. P., Wilhalm, T. \& Conti, F. 2018: An updated checklist of the vascular flora native to Italy. - Pl. Biosyst. 152: 179-303. https://doi.org/10.1080/11263504.2017.1419996

Borzì, A. 1911: Le querce della flora italiana. Rassegna descrittiva. - Boll. Reale Orto Bot. Giard. Colon. Palermo 10: 41-66.

Brullo, S. 2017: Quercus L. - Quercia. - Pp. 686-697 in: Pignatti, S., Guarino, R. \& La Rosa, M. (eds), Flora d'Italia, Ed. 2, \&. Flora Digitale, 1. - Milano.

—, Guarino, R., Siracusa, G. 1999: Revisione tassonomica delle querce caducifoglie della Sicilia. Webbia 54: 1-72. 
Bruschi, P. \& Grossoni, P. 2004: Variabilità morfologica e molecolare in Quercus pubescens (Willd.) dell'Italia centro-meridionale - Inform. Bot. Ital. 36: 529-531.

—, Vendramin, G. G., Bussotti, F. \& Grossoni, P. 2000: Morphological and molecular differentation between Quercus petraea (Matt.) Liebl. and Quercus pubescens Willd. (Fagaceae) in northern and central Italy. - Ann. Bot. 85: 325-333.

_, - , — \& - 2003: Morphological and molecular diversity among Italian populations of Quercus petraea (Fagaceae). - Ann. Bot. 91: 707-716.

Burger, W.C. 1975: The specie concept in Quercus. - Taxon 24: 45-50.

Bussotti, F. 2020: Quercus L. - Pp. 200-265 in: Grossoni, P., Bruschi, P., Bussotti, F., Pollastrini, M. \& Selvi, F.: Trattato di botanica forestale, 2. Le angiosperme. - Milano.

— \& Grossoni, P. 1997: Querce europee e mediterranee: problemi tassonomici. - Italia Forest. Mont. 52: 240-260.

— \& - 1998: Des problèmes dans la classification des chênes. Taxonomie en Europe et région méditerranéenne. - Forêt Médit. 19: 267-278.

-, Pollastrini, M., Holland, V. \& Brüggemann, W. 2015: Functional traits and adaptive capacity of European forests to climate change. - Environm. Exper. Bot. 111: 91-113. https://doi.org/10.1016/j.envexpbot.2014.11.006

Camus, A. 1936-1939: Les chênes: monographie du genre Quercus, 1, 2. - Paris.

Corona, P., Macrì, A. \& Marchetti, M. 2004: Boschi e foreste in Italia secondo le più recenti fonti informative. - Italia Forest. Mont. 2: 119-136.

Corti, R. 1959: Ricerche sul ciclo riproduttivo di specie del gen. Quercus della flora italiana. IV. Osservazioni sulla embriologia e sul ciclo riproduttivo di Quercus ilex. - Ann. Accad. Ital. Sci. Forest. 8: 19-42.

Denk, T. \& Grimm, G. W. 2010: The oaks of western eurasia: traditional classifications and evidence from two nuclear markers. - Taxon 59: 351-366.

—, - Manos, P. S., Deng, M. \& Hipp, A. L. 2017: An updated infrageneric classification of the oaks: review of previous taxonomic schemes and synthesis of evolutionary patterns. - Pp. 13-38 in: Gil-Pelegrin, E., Peguero-Pina, J. J. \& Sancho-Knapik, D.: Oaks, physiological ecology. Exploring the functional diversity of genus Quercus L. - Tree Physiol. 7. - Cham.

Di Noto, G., Grossoni, P. \& Bussotti, F. 1995: Variabilità morfologica di piante del genere Quercus (Fagaceae) nel territorio delle Madonie: confronto fra exsiccata dell'Herbarium Panormitanum e campioni raccolti in natura. - Inform. Bot. Ital. 27: 303-304.

Di Pietro, R., Viscosi, V., Peruzzi, L. \& Fortini, P. 2012: A review of the application of the name Quercus dalechampii. - Taxon 61: 1311-1316.

—, Di Marzio, P., Medagli, P., Misano, G., Silletti, G., Wagensommer, R. \& Fortini, P. 2016: Evidence from multivariate morphometric study of the Quercus pubescens complex in southeast Italy. - Bot. Serbica 40: 83-100.

-, Conte, A. L., Di Marzio, P., Gianguzzi, L., Spampinato, G., Caldarella, O. \& Fortini, P. 2020a: A multivariate morphometric analysis of diagnostic traits in southern Italy and Sicily pubescent oaks. - Folia Geobot. 55: 163-183. https://doi.org/10.1007/s12224-020-09378-0

—, —, —, P., Fortini, P., Farris, E., Gianguzzi, L., Müller, M., Rosati, L., Spampinato, G. \& Gailing, O. 2020b: Does the genetic diversity among pubescent white oaks in southern Italy, Sicily and Sardinia islands support the current taxonomic classification? - Eur. J. Forest Res. 140: 355-371. https://doi.org/10.1007/s10342-020-01334-z.

—, Di Marzio, P., Antonecchia, G., Conte, A. L. \& Fortini, P. 2020c: Preliminary characterization of the Quercus pubescens complex in southern Italy using molecular markers. - Acta Bot. Croat. 79: 15-25.

Di Tella, G. 1930: La farnia. - L'Alpe 17: 351-356.

Enescu, C. M., Curtu, A. L \& Șofletea, N. 2013: Is Quercus virgiliana a distinct morphological and 
278 Grossoni \& al.: The taxonomic interpretation of Mediterranean oaks of Quercus L....

genetic entity among European white oaks? - Turk. J. Agric. Forest. 37: 632-641.

Grossoni, P. \& Bruschi, P. 2014: A proposito delle querce. - Pp: 223-236 in: Cianfaglione, K. (ed.): L'importanza degli alberi e del bosco. - Trento.

Fineschi, S. \& Vendramin, G. G. 2004: La diversità cloroplastica delle querce italiane: evidenze di una maggiore ricchezza genetica nelle popolazioni meridionali e insulari. - Forest@1: 82-87.

Fiori, A. 1923-25: Quercus L. - Pp. 361-367 in: Fiori, A.: Nuova flora analitica d'Italia, 1. - Firenze.

- 1930: Le querce roveri. - Alpe 17: 348-350.

Greuter, W., Burdet, H. M. \& Long, G. 1986: Med-Checklist. A critical inventory of vascular plants of the circum-mediterranean countries. 3. Dicotyledones (Convolvulaceae-Labiatae). - Berlin.

Le Hardÿ de Beaulieu, A. \& Lamant, T. 2010: Guide illustré des chênes, 1-2. - Geer.

Krüssmann, G. 1986: Manual of cultivated broadleaved trees and shrubs, 2. - London.

Linné, C. 1753: Species plantarum. - Stockholm.

Médail, F. \& Quézel, P. 1999: Biodiversity hotspots in the Mediterranean basin: setting global conservation priorities. - Conserv. Biol. 13: 1510-1513.

—, Monnet, A.-C., Pavon, D., Nikolic, T., Dimopoulos, P., Bacchetta, G., Arroyo, J., Barina, Z., Albassatneh, M. C., Domina, G., Fady, B., Matevski, V., Mifsud, S. \& Leriche, A.: 2019: What is a tree in the Mediterranean basin hotspot? A critical analysis. - Forest Ecosyst. 6: 17. https://doi.org/10.1186/s40663-019-0170-6.

Merendi, A. 1930: La rovere. - Alpe 17: 357-364.

Nixon, K. C. 1993: Infrageneric classification of Quercus (Fagaceae) and typification of sectional names. - Ann. Sci. Forest. 50: 25s-34s.

Ørsted, A. S. 1871: Bidrag til kundskab om egefamilien i nutid og fortid. - Kongl. Danske Vidensk. Selsk. Skr. Naturvidensk. Math. Afd. 5(9): 331-538.

Pignatti, S. 1982: Quercus L. - Pp. 113-120 in: Flora d'Italia, 1. - Bologna.

Rushton, B. S. 1993: Natural hybridization within the genus Quercus. - Ann. Sci. Forest. 50: 73s-91s.

Salvini, D., Bruschi, P., Fineschi, S., Grossoni, P., Kjær, E. \& Vendramin, G. G. 2009: Natural hybridisation between Quercus petraea (Matt.) Liebl. and Quercus pubescens Willd. within an Italian stand as revealed by microsatellite fingerprinting. - Pl. Biol. 11: 758-765.

Schwarz, O. 1936-39: Monographie der Eichen Europas und des Mittelmeergebietes. - Repert. Spec. Nov. Regni Veg., Sonderbeih. D: 1-400. - Berlin.

— 1964: Quercus L. - In: Tutin, T. G., Heywood, V. H., Burges, N. A., Valentine, D. H., Walters, S. M., \& Webb, D. A. (eds), Flora europaea, 1. - Cambridge.

- 1993: Quercus L. - In: Tutin, T. G., Burges, N. A., Chater, A. O., Edmondson, J. R., Heywood, V. H. \& Moore, D. M (eds), Flora europaea, ed. 2., 1. - Cambridge.

Wellstein, C. \& Spada, F. 2015: The status of Quercus pubescens Willd. in Europe. - Pp. 153-163 in: Box, E. O. \& Fujiwara, K. (eds), Warm-temperate deciduous forests around the northern hemisphere. - Geobot. Stud. - Cham.

Whittemore, A. T. \& Schaal, B. A. 1991: Interspecific gene flow in sympatric oaks. - Proc. Natl. Acad. Sci. U.S.A. 88: $2540-2544$.

Address of the authors:

Paolo Grossoni, Piero Bruschi, Filippo Bussotti*, Martina Pollastrini \& Federico Selvi, Department of Agriculture, Food, Environment and Forestry (DAGRI), University of Firenze. Piazzale delle Cascine 28, 50144 Firenze, Italy.

* Corresponding author. E-mail: filippo.bussotti@unifi.it 